\title{
Virunga National Park, the heart of darkness as UNESCO World Heritage
}

Frits Andersen

\section{OpenEdition}

\section{Journals}

Electronic version

URL: https://journals.openedition.org/coma/2773

DOI: $10.4000 /$ coma. 2773

ISSN: 2275-1742

\section{Publisher}

Institut des textes \& manuscrits modernes (ITEM)

Electronic reference

Frits Andersen, "Virunga National Park, the heart of darkness as UNESCO World Heritage", Continents manuscrits [Online], 11 | 2018, Online since 15 October 2018, connection on 12 January 2023. URL: http://journals.openedition.org/coma/2773 ; DOI: https://doi.org/10.4000/coma.2773

This text was automatically generated on 12 January 2023.

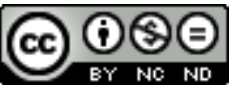

Creative Commons - Attribution-NonCommercial-NoDerivatives 4.0 International - CC BY-NC-ND 4.0 https://creativecommons.org/licenses/by-nc-nd/4.0/ 


\title{
Virunga National Park, the heart of darkness as UNESCO World Heritage
}

\author{
Frits Andersen
}

Parc National des Virunga was established in 1925 as the first national park in Africa. It covers an area of $7,800 \mathrm{~km}^{2}$, bordering on Parc National des Volcans in Rwanda and Rwenzori Mountains National Park in Uganda. Virunga has been appointed a UNESCO World Heritage Site and constitutes, together with the adjacent parks, one of the most prestigious sites in the world. There are still a few hundred endangered mountain gorillas left, as well as okapis - a species that was only 'discovered' by Europeans in 1901, having until then only heard about the zebra-like giraffe as the 'African unicorn'. There are also populations of straight-tusked and bush elephants, buffalos and chimpanzees. The multitude of nature and climate varieties, with large lakes, savannas, vast forest areas, snow-covered mountain tops, tropical swamps, erupting volcanos, and grass-covered meadows provide habitats for the large mammals we associate with the wild nature of Africa.

When Henry M. Stanley travelled through the area around Lake Victoria on his transatlantic Africa expedition 1874-77, he described it as 'the Pearl of Africa'. This was an area with an immense wealth of resources - a bright, brilliant and habitable place for an exemplary civilisation - and he invited "philanthropical capitalists" to carry out free trade there to abolish slave trade and settle conflicts between the various native tribes (Stanley p. 191-222). For instance, he imagined, in his well-known exaggerated, ecstatic and utopian style, a railroad connecting the highlands in Africa's Lake District, which was to resolve conflicts through trade at the same time as offering immense pleasure to travellers who would take in the panoramic vistas of the extraordinarily beautiful landscape. Furthermore, Stanley's descriptions confirm a long-standing tradition for ascribing profound historical and mythological significance to the area around the Virunga and Rwenzori Mountains - something that is in stark contrast to the widespread conception of Africa as devoid of history. This was where Ptolemy situated the legendary Mountains of the Moon and where the source of the Nile - and thus the ancient civilisations - was to be found. It was also here that Stanley believed it 
was possible to trace fabled kingdoms that, according to legend, were established in central Africa in the early years of Christianity (Stanley p. 337-407).

It was common among explorers of the Victorian era to situate the highest developed African cultures in this area and thereby depict the area as a high point in both a topographical and civilizational sense (Burton, Speke, Stanley, Jephson). Today, however, the Virunga and Rwenzori Mountains have been taken hostage and are haunted by the 'heart of darkness' narratives which find their sources in Joseph Conrad's novella. Moreover, this is the case for the entire Congo and, through the pervasive metaphor, the entire sub-saharian Africa. The geophysical location of the 'heart of darkness' as a rhetorical image of a place where the horrors surpass our imagination has moved topographically from the area around Stanley Pool to the Kivu Province, Rwanda, Burundi, and the border regions towards Uganda. The genocide in Rwanda in 1994 gave rise to vast waves of immigration into DR Congo and, consequently, a civil war that has ravaged the region ever since, with few and brief pauses.

Over this period, the Virunga and Rwenzori areas have been highly unstable. As a significant element in the military strategy, a vast number of militias - competing with the Congolese government army - are perpetrating the most bestial crimes against civilians: murder, systematic 'rape warfare', other sexual violence, and abductions of civilians to be used as sex slaves or child soldiers. The national borders do not offer safe demarcations of states but are overruled by changing and cross-border alliances that are no longer ethnically defined. Rather, the borders are determined by the financial interests of the involved militia leaders or 'counts', focusing on the vast deposits of diamonds, gold, uranium and, particularly, coltan: a mineral that is used for making mobile phones, and which the volcanos of the mountain ridge have spewed out for aeons and today has become a curse on the area. The borders of the national park are also threatened, partly due to the siege of greedy militias because the coveted minerals are also found here, and partly due to the drastically increasing pressure on nature caused by the wave of destitute refugees who resort to poaching and charcoal burning.

The British oil company SOCo have used illegal concessions, granted by the Congolese government, to locate large oil deposits beneath Lake Edward, which is a part of the Virunga Park, adding yet another cynical dimension to the existing pattern of international destruction and plundering of the country. Not only has this plundering by proxy resulted in immense suffering for the region's inhabitants, but the region understood as both nature and place is also threatened by destruction - not as commonplace but shared place: the biological, anthropological, mythological and historical origin of mankind and our relatives.

As a direct consequence of the British documentary film Virunga (2014), which revealed soco's hole-and-corner methods and the threat against the gorilla population in the park, SOCO entered into an agreement with WWF to refrain from carrying out surveys that would harm the unique environment. However, as was expected by NGOs such as Global Witness and Human Rights Watch, the agreement between DR Congo and UNESCO that has so far ensured the area's status as world heritage site is continuously under strong pressure. On 14 March 2015, BBC News Africa reported that DR Congo is planning to revise the borders of the national park in order to ensure that SOCO can obtain oil from the ground underneath the highly vulnerable Lake Edward without being impeded by nature protection conventions. As stated by the director of the 
Virunga Park, there is a risk of spills that would reach the Spanish coast via the Nile and the Mediterranean, thereby not only polluting what is increasingly conceived of as a non-place in Africa but also our part of the world and ourselves. ${ }^{1}$ Environmental organizations raised the alarm following statements from President Kabila and Oil Minister Aimé Ngoy Mukena at the beginning of 2018 in which they said that the government is willing to allow oil extraction from the nature reserves of DR Congo - a permission that was finally granted in July $2018 .^{2}$

If it were not contradictory to the conception of a continent often illustrated by Hegel's infamous claim that 'Africa has no history', these savage mountains deserve, more than anywhere else in the world, to be termed 'a classical place'. By this, I mean that the area, in a historical and anthropological sense, is loaded with significance. However, the geocritical approach of the present article also builds on the idea that, firstly, such places are discursively and performatively formatted and, secondly, that these discourses - e.g. common animal programmes on TV - in combination with geophysical and historical forces on location not only create or destroy local topographical preconditions for life but also determine the relationship between Europe and Africa and possible interventions. The critical perspective of the article concerns the fact that the threat against Virunga means not only running the risk of losing a unique place in the world, where the extinction of the gorilla is, more than anything, sad but moreover an all too realistic scenario; on a larger scale, it also means running the risk of losing both 'Africa' and 'a global sense of place' (Massey). Following Doreen Massey's theory of places, my article argues that the Virunga National Park may lose its placeness. It happens when the history of the park and its complex ethnic and political situations are constantly erased and actively forgotten through the media's simplistic use of atrocity tales, perpetuating the demonizing features of Conrad's Heart of Darkness. The article outlines how human rights and animal protection campaigns since the Congo Reform Movement have contributed to and reinforced the horror rhetoric currently affecting the world's approach to Virunga, thus threatening to destroy the placeness of the park - reduce the preservation value of the place - and thereby pave the way for the extraction of raw materials and the risk of ecological disaster.

\section{The Congo Reform Movement Atrocity Campaign}

Following increasing numbers of reports from mainly Protestant missionary movements on plundering, hostage taking and the killing of natives in connection with the intensified collection of crude rubber in the Congo, a reform movement based in England was formed in 1905. After a gruelling struggle fought through the media, King Leopold was forced to hand over the Congo Free State to the Belgian state in 1908. The leading figure in the movement, the journalist Edmund Morel, was from the outset sceptical towards the reports of atrocities that reached London from the missionaries. He defended the Congo Free State against the attacks but later became the main writer and strategist for the campaign, known particularly for the bestseller Red Rubber. The Story of the Rubber Slave Trade Flourishing on the Congo in the Year of Grace 1906 (1906). Morel changed his opinion after a meeting in 1899 with Mary Kingsley, who developed a specific concept of free trade during two long-term trips to West Africa. Kingsley's key point was that colonial powers ought to acknowledge and respect African societies as rational and efficient on their own terms, rather than subjecting them to European re-education programmes. This was an expansion of the free trade doctrine and the 
British formula for 'indirect rule', emphasizing that free trade also related to the natives' right to trade with whomever they wanted and that there was a shared interest for both the colonizer and the colonized in developing existing means of production and forms of trade rather than destroying them.

As established by the historian Kevin Grant, the reform movement did not achieve its immense historical impact until the inclusion of the effective propaganda system of the missionary movement. While Morel was sceptical towards 'missionary evidence' and tried to avoid evangelical rhetoric in the abolitionist campaigns, hoping to underpin the legal validity of the evidence, this rhetoric was generally reinforced when the Protestant missionary movement took over the logistical organisation of the Congo Reform Movement, which spread to the European mainland and the USA. Thousands of 'atrocity meetings' were held in churches and missionary buildings, often attracting thousands of participants. And even though the missionary movement had not played any significant part in the critique of misdeeds from the beginning of the Red Rubber regime, the depopulation of nearby villages became important to their missionary efforts. Humanitarian 'crusades' became a main cause for the missionary movement, which also harvested the highest economic and political yield - both in relation to efforts in the Congo and in relation to strengthening the role of the organization as a domestic political power in England (Grant, "Christian critics of empire").

The meetings, also known as 'lantern lectures', were held in accordance with a tried and tested recipe, based on a readymade concept that was distributed internationally: The Congo Atrocities. A Lecture to Accompany a Series of 60 Photographic Slides for the Optical Lantern. In accordance with the manual, special Congo hymns were sung at certain points during the lecture, and testimonies or what the missionaries called 'horror narratives' were shared. The meetings or 'lectures' were organized as sermons while using modern media technology that had until then been successfully used in popular Laterna Magica freak shows on market places to an almost mass-hypnotizing effect. Reports from these meetings testify of very strong emotional reactions among the audience, who would stand up and scream out their indignation or fall into a trancelike state until the 'lecturer' brought the event to an end in a more calming tone, saying an evangelical prayer for hope and salvation that would result from the audience's political support for the Congo Reform Movement and donations to the missionary effort in Africa (Grant, "Christian critics of empire"; Peffer).

An important element in the campaign strategy was to disseminate photos of mostly children, with their hands and feet chopped off. These photos were presented without an explanation of the context, the complexity of which would only have obstructed the intended effect on the viewer. However, the photos are ambiguous and disturbing in a manner that is counterproductive to the intention. Susanne Gehrmann, among others, has argued that the photos of mutilations are cropped and staged with the campaign in mind and often presented through a problematic association of voyeuristic pleasure and moral outrage that is degrading for the people depicted (Gehrmann; Thompson; Twomey). Further, many of the photos raise the suspicion that mutilation may have been carried out in view of the photographic staging. For instance, photos that depict chopped-off hands and feet are intrinsically self-contradictory. They appear as evidence of the Free State soldiers' infamous practice of chopping off the hands and feet of their dead victims as a currency of exchange for new ammunition. However, the testimony is undermined by the photo itself: the body parts are clearly not in the 
possession of the soldiers, raising unpleasant questions about how they nevertheless ended up in the photo.

In a study on the role of photography in humanitarian media campaigns, Sharon Sliwinski notes three circumstances regarding the Congo Reform Movement: individual stories and photos were anonymized and mass-produced without any certain reference to time and place; the displays established a standard for reproduction of a narrative structure for presenting testimonies, a so-called 'standard narrative'; and, most significant to her critique, perception took place in a communicative situation that was fundamentally phantasmagorical and hallucinational: feverish. The specific characteristics of individual cases were erased and transferred to a standardised, recognisable version that was built up around the powerful images of chopped-off hands and feet, bringing the audience to draw universal conclusions on the rights of others. In this sense, the main objection is that the sensory raw material for the modern, international model of responsibility and rights was made up of this 'dreamwork'. John Peffer points out a similarly problematic connection between the Congo Reform Movement and subsequent human rights campaigns. The slide shows evoked strong emotional response, but in a hypnotized context whose effect relied on forgetfulness and repression of the context of the atrocious images, including the omission of the missionaries' active participation in both the colonial exploitation and staging of e.g. public whippings. The Harris couple, who provided most of the photos, did in fact carry out whippings of natives themselves. With reference to Susan Sontag's "Regarding the Pain of Others", Peffer argues that "sentimentality", as Susan Sontag has cautioned, "notoriously, is entirely compatible with a taste for brutality or worse", and sympathy may also serve to mystify real relations of power by simultaneously imagining proximity and enforcing distance between metropolitan observers and exoticized victims. Further, Peffer states that any repetition of the misdeed, in the missionaries' staged displays in Africa as well as during slide shows in Europe, is an exercise of violence ${ }^{3}$. In a performative view, the reform movement campaign established the idea that audiences, through visual confrontation with atrocious acts, can abolish the effect of these acts from a distance through passive compassion for the victim. When this mechanism is simultaneously linked to universal and transcendent notions of humanity, dignity and duty, Sliwinski claims that any clear idea of the reality of the people involved is repressed, which continues to be a problem in presentday human rights movements or similar forms of "liberal humanitarian discourse" (Sliwinski; Peffer; Thompson).

\section{Gorilla Protection Campaigns}

Several passages in Stanley's travel account from the transatlantic Africa expedition discuss the possible species and development relations between chimpanzees and, for example, Pygmies, as viewed in relation to Europeans as the highest level of humanity and including hypotheses about gorilla-like beings as 'missing links'. By the end of the 19th century, reflections like these were required of Victorian explorers who were also expected to bring back skulls of both apes and humans for anthropometric study in London. The macabre circumstances regarding the acquisition and conservation of specimens often added fuel to the already blazing debate triggered by Darwin's controversial theses. In addition to the furious discussion about how to distinguish morally between humans and animals, there was controversy between those who 
claimed that different races represented different species of human, which legitimized the contention that apes and 'negroes' were closely related, and those who, often with a basis in the abolitionist movement, supported monogenism, which distinguished between apes and humans and thereby placed different human races on the same biological evolutionary level. In the wake of the American Civil War, there was a renewed interest in the question of the biological being of the 'negro' - a discourse that included religious, scientific, moral and political-economic aspects (Hodgson). Therefore, the interest in 'missing links', i.e. discoveries of humanoid species that may provide ultimate proof for one view or the other, was also immense.

This intense media context ensured that the French-American adventurer and explorer Paul du Chaillu's descriptions of gorillas received huge attention. The first scientific description of gorillas was written by Thomas Savage in 1847, but it was du Chaillu's Explorations and Adventures in Equatorial Africa of 1861 that made the gorillas famous in popular culture (Conniff). Du Chaillu's dubious national affiliation - he was born in Réunion Island to a mulatto mother and a French father and spent the first years of his life in Gabon - was used in combination with his 'French' manners and broken English to account for his tendency to exaggerate and thus to sow doubt about his accounts (Lifshey). Du Chaillu's gorilla accounts were discussed intensely in a field of tension where the gorilla was at the same time a valuable scientific trophy and a metaphor for unreliability. The popular cultural interest gave rise to a multitude of gorilla texts, gorilla pamphlets, gorilla reviews, gorilla quadrilles, gorilla songs and gorilla poems that typically employed the rhetorical technique of placing the gorilla as an 'I' - a subject making moral-serious or satirical speculations about its own species and that of the human, who had now interrupted thousands of years of peace from civilisation (Hodgson).

Towards the end of the 19th century, partly motivated by so-called 'gorilla abduction tales' among both natives and Europeans - stories about gorillas abducting women and subjecting them to their masculine needs - the gorilla became a generalised symbol for quasi-phenomena and hybrid species (Giles-Vernick and Rupp). The gorilla represented the point at which human and animal part ways but was also described in hybrid genres where fact and fiction were inseparable. In that sense, gorilla tales belong to the genre that is termed ecogothic, i.e. characteristic of tropes that play out transgression of boundaries between genres, species and bodies: previous development steps haunted and positions tested, on the one hand allowing for non-human species' nonanthropocentric gaze on humans and, on the other hand, describing this possibility as monstrous and horrifying. This genre can ultimately be seen to express 'speciesism' in the form of a centrist perception of a hegemony of species (Miller). In contrast to the popular cultural idea of the gorilla, which in fin de siècle culture was also linked to the fearful and pleasurable Freudian fascination of the human as a being driven by desire including the fantasies about women whose innermost desire was to be taken by virile male gorillas, and literary decadence with its fascination with 'ape-men' - du Chaillu attempted to present his gorilla discoveries in a context that was both scientific and popular.

In du Chaillu's The Country of the Dwarfs from 1901, above the caption "How to photograph gorillas", is an illustration depicting how the first photo of a living gorilla was taken. The reason he managed to take the photo with the heavy equipment was that the gorilla mother had died and the young was clinging to her breast for milk and 
care. "The mother's death was painful for the young in the same way as for a human", adds du Chaillu to the description of the "peculiar being that God almost created in the image of man." The photo was lost but still forms part of the context for evidence and proof that Mark Twain mentioned in connection with the Congo Reform Movement's use of 'the incorruptible Kodak' (Twain). At the same time, its macabre context in the form of both self-staging and du Chaillu's gory tales of gorilla hunting and cannibalism links to the gothic 'atrocity meetings' of the era. Du Chaillu recounted and illustrated the story in the book and repeated it at talks to the National Geographic Society back in America, where gorilla tales drew huge crowds and contributed to consolidating the organization and the subsequent National Geographic magazine. Years later, in relation to the controversy surrounding Dian Fossey, photos in National Geographic became instrumental in raising money for the endangered species. The primatologist Dian Fossey's account of a rescue mission funded by National Geographic in the border region between the Congo and Rwanda, Gorillas in the Mist from 1981, and the subsequent film adaption, further appear to both repeat and reverse a vast number of figures from the primitivism and gothic of fin de siècle culture. Both book and film appear as both 'atrocity' campaign and gorilla hype that can be viewed as titillating reactions to the notion that the definition of man as being above animal instinct is deteriorating.

Read through the perspective of her own narrative and as the puzzle has been pieced together by biographies attempting to explain her strange life and mysterious death, the story of Dian Fossey is a 'go native' tale that broadly follows Conrad's story about Kurtz. In order to protect the animals, which she values higher than humans, Fossey is ready to transgress the established norms of civilisation and launch the usual repertoire of punishment and scare campaigns (Hayes, Whitlock). Intent on subjugating the natives living in the reserve, she acts as a sorceress whose fetishes can cast fearsome curses, and she burns down villages, kidnaps children and arranges lynching and torture. Within the borders of the reserve, she thereby realizes a colonial rule based on a mix of totalitarianism and sorcery, opposing the natives, who have lived in the area before it became a reserve, and the local authorities, who see Fossey's arbitrary methods as a large problem for the proceeds from tourism that are vital to the impoverished district. ${ }^{4}$

Fossey's fundraising campaign involves rhetoric that is similar to that of the abolitionist movement, utilizing photo campaigns that are distributed to the waiting rooms of medical clinics across the world via National Geographic, depicting the habitats of gorilla families as original pastoral idylls and showing abuse and mutilation. Also in parallel to the abolitionist movement, the campaign results in increased demand for gorillas from zoos around the world, paving the way for increasing intrusion of poachers and illegal operations in the reserve. Gravitating around the large male gorilla named Digit, the film Gorillas in the Mist: the Story of Dian Fossey, featuring Sigourney Weaver, especially wallows in gory images of mutilated apes with hands and feet chopped off, referring directly back to the Congo Reform Movement and its display of atrocities. The fundraising that initially took place through organizations such as the Dian Fossey Gorilla Fund International and the Digit Fund in the UK subsequently continued via campaigns that exploited Fossey's world famous brand, even though the same organizations eventually turned their backs on her before her brutal and unsolved murder. 
Fossey's own story, the earliest campaigns, films and biographies such as Harold Hayes' The Dark Romance of Dian Fossey (1990) all contribute to shaping a modern myth that reproduce central characteristics and rhetoric from early human rights campaigns. In National Geographic, on the website for the Dian Fossey Gorilla Fund International and in other media, this process can be witnessed in the form of current responses to the threat against the mountain gorilla posed by the ongoing civil war. One of the effects of this rhetoric - which is canvassed in the global news media - is that the animals appear more human than the humans living in the region and in more dire need of a humanitarian effort, while the human victims of the war are all but forgotten.

Many things indicate that in her early campaigns, Dian Fossey consciously employed established rhetorical figures of disgust and compassion associated with the Congo since Conrad, but that she was subsequently caught up in her own 'dark romance' just like Kurtz. The fascinating story is of course enforced by the guesswork regarding who murdered Fossey, fueled by the testimonies at the International War Crimes Tribunal following the genocide in Rwanda.

Dian Fossey's legacy and the influence of her controversial work are continuously contested, both by the gorilla protection programmes and funds that use her name and brand, and among those who shed critical light on her methods, which pose both specific and general problems in primatological research, and her results, which were few and insignificant from a scientific point of view (Haraway). Those who still honour her legacy claim that Fossey saved the mountain gorillas from complete extinction and contributed to a significant increase in their population by resolutely confronting poachers and other gorilla organizations that operated in the area via funding from gorilla tourism, causing the deaths of many gorillas due to the transfer of infectious diseases such as influenza. Others view her as a colonial ruler who, by use of the same spectacular media violence and scare campaigns that make the local war lords infamous, kept rivals away from the area. For example, it has come to light that during her trips to the USA Fossey bought large stocks of fireworks and 'magical' Halloween paraphernalia for the purpose. In the present context, however, it is her rhetorical and medial configuration of the place and the relationship between human and ape that is of most interest.

Fossey's autobiography edits out almost all traces of the author's life story, which is in keeping with her statement that she would have preferred to be completely absent so that the gorillas could take the place as the biographical main characters. This leaves her own part to hover 'in the mist', just like the gorillas, because it conceals the fact that her activism was not only orientated towards the native Batwa but also had an active impact on the gorillas' environment. Because her primatology was based on behavioural studies and closeness, it also entailed a large risk of transferring diseases and making the animals accustomed to humans, which facilitated poaching and tourism and changed the gorillas' behaviour. When the Rwandan authorities and rival gorilla protection programmes on the one hand praised Fossey for paving the way for gorilla tourism and, on the other hand, accused her of being responsible for the poaching of her beloved Digit and Uncle Bert, they were probably correct in both cases. Digit was found with his head cut off and his hands removed with the intention of being sold as ashtrays that can fetch 10 dollars apiece on the market. Fossey wanted to use photos of his mutilated body on posters reading 'Come visit me in Rwanda', in films and articles with "pictures of Digit alive and in death in any nature protection magazine I 
can get my hands on" (Mowat 169). Her disguised author subject in the autobiography is also in keeping with the media campaign that she sped up after Digit was killed. She established the Digit Fund and allowed the photographer Ian Redmond and a BBC crew to film the mutilated body in detail, while her own intensified and brutal interrogations of - and warfare against - natives was kept out of reach of camera lenses. Bob Campbell relates in the National Geographic documentary from 2002, The Lost Film of Dian Fossey, which shows previously unreleased recordings from the time in the Virunga Mountains, that he was the first person to encourage Fossey to do her imitations of gorilla behaviour that later made her famous, in order to get closer to the wild animals and become able to produce the moving and iconic images of physical contact between gorilla and human. However, Fossey demanded that films and photos addressing the world audience of National Geographic kept the photographer or camera out of the shot.

These staged and edited visual narratives for the influential, globally published magazine had a range of effects. Firstly, and most obviously, they established the gorillas' habitat as an exception where man-as-gorilla and the mountain gorilla in its innocence before the Fall vegetate at a shielded distance from civilization, which functions as an antithesis: hell on earth. Outside the enclave, rhetorical and physical violence is needed to secure the border from inhumane people. Inside the enclave, people live in a posthuman - or rather pre-human - state, like peaceful animals, side by side with anthropomorphized gorillas, honouring long-forgotten human virtues such as chivalry and dignity. The passage between the two worlds consists of a secret tunnel, equivalent to the one that connects two parallel universes in science fiction, and the basic rhetorical formula combines prosopopeia, antithesis and inversion with the aim of depicting a utopian island in ecological balance and undivided, nonlinguistic understanding between the gorillas and the returned primatologist.

\section{Virunga - the Documentary}

Virunga is directed by British Orlando von Einsiedel and premiered in April 2014. It has been nominated for several prizes, including the 2015 Academy Award for Best Documentary Feature. It received only favourable reviews and has been featured on Netflix. The film crew travelled to Virunga National Park with the intention of documenting the positive development in tourism and associated effects. However, after only three weeks, the infamous rebel group M23 launched an attack against the government troops, which also threatened the park and the park authorities, causing the crew to change focus from the positive story about progress - positive reports from Africa are in high demand as a counter-reaction to the one-sided media pessimism regarding the continent - to a coverage of the complex conflict. The film follows four main characters: Park Director Emmanuel de Merode, a member of the Belgian royal family who has devoted his life to preserving the natural resources and - in contrast to King Leopold under the Free State regime - appears uncompromising and incorruptible; leader of the rangers that patrol the park for poachers Rodrigue Mugaruka Katembo; gorilla keeper André Bauma; and French journalist Mélanie Gouby, who is already situated in Goma and seizes the chance to write a story that digs deeper into the conflict than the usual sensational reports on the terrors of the war.

Similarly to the Dian Fossey film, there are close-ups of mountain gorillas peacefully grazing on the mountainsides, a moving story centred around André Bauma's solicitous 
care for sick or abandoned gorilla babies, and aerial shots where the unique landscape, with its glowing orange-red volcanos and every shade of green, stuns the viewer with its sublime beauty. However, in contrast to Fossey, Bauma makes a strict distinction between his gorilla and human families, and the landscape is not configured through an antithesis, where the locus amoenus of the Fossey films depict an innocent natural state where time stands still as an antithesis to the locus horribilis that is the barbarianism of civilization. The boundary between inside and outside is depicted as porous and defined by the power relations that currently dominate the place, and it is therefore negotiable and does not pay heed to universal animal or human rights. Most importantly, the film illustrates how the medial staging of the conflict is at the same time part of the conflict. This happens through recordings with spy cameras, which - as Emmanuel de Merode explains - are crucial weapons in a war that he and his rangers would never be able to win with firearms, and through the end credits that point out the political aftermath of which the film itself is an evident part.

Instead of focusing on the classical distribution or light and darkness and the appeal to compassion in the gorilla tale, the film reveals a far more profound explanation to the ecological crisis: Rodrigue Katembo's spy camera recordings show that the oil company SOCO's illegal explorations in the area have triggered M23 to recommence the fighting. The militia is promised a share in the enormous oil profits in return for arranging bribery of the park rangers and scare campaigns against both local authorities and inhabitants who live off fishing in Lake Edward. SOco's plan is to have the park declassified. As the local head of SOCO states with cynical and reversed logic: a park where oil drilling takes place cannot be a UNESCO World Heritage Site. Emmanuel de Merode receives death threats because he refuses to budge, and Mélanie Gouby's spy cam recordings of conversations with the local head of SOCO and his security manager provide an image of an intransigent organization that is willing to resort to any means available: the local population are referred to as helpless children who would be best served with the Europeans regaining full control; it would be ridiculous if some 'fuckin' monkeys' should stand in the way of exploiting the oil deposits; etc.

Emmanuel de Merode miraculously survives being shot at close range on his way home to Virunga after having handed in a critical report on the SOCO activities to the government in Kinshasa. Rodrigue Katembo is detained and tortured because he is one of the few rangers who will not accept bribes. SOCO deny any involvement in the shady business but nevertheless enter into an agreement with the World Wildlife Fund to refrain from causing damage to the environment of the reserve, prompted by the film. As mentioned above, the agreement is termed 'a ruse' by Global Witness and Human Rights Watch, which is confirmed only a few days later by SOCO's chairman of the board, Rui de Sousa, who says: "We haven't pulled out - that's not the point at all." Instead, the company starts investigating the possibilities for changing the reserve borders, and an announcement on 14 March 2015 from the Congolese government indicates that this has probably been the plan from the outset.

According to environmentalists, this outcome will be a disaster - not only for the mountain gorillas and the Virunga Park but for all national parks in Africa, where corrupt governments in what V.S. Naipaul referred to as 'half-made societies' can be bought by multinational corporations in return for a slice of the pie. All this will take place while the affected populations can only look forward to even further destruction of environment and livelihood, even though the governments' agreements on extended 
concessions are made on the premise that the consideration of poverty and misery among the local population is weightier than the care for endangered animal species.

Thanks to the Virunga film exposing the financial-political reasons behind the ecological and humanitarian crisis in the area, which is extended and worsened because of SOCO's presence, it has become clear that both animal and human rights campaigns, with their atrocity tales and appeal to compassion with animals and humans, are left powerless when facing the forces that destroy a place of 'unique, universal value' for all mankind. The head of Soco's security forces in the area clearly states in the film that the only universal truth concerning Africa is that 'business is business is business'.

Viewed as discourses, both human and animal rights campaigns are rooted in the same basic rhetorical patterns that date back to the agitation of the abolitionist movement. They presupposed a topographic distribution between darkness, whose savagery was to be replaced by the gospel, and paradisiacal glades, where natives danced around in childish innocence, justifying the missionary movement and its presence. As mentioned above, this figure obtained a particular gothic twist in the fin de siècle culture and its fascination with horror connected to the non-humane that entailed both 'atrocity meetings' and gorilla fascination. In modern day campaigns and global mass media such as National Geographic, pathetic compassion with animals and humans only serves to divert attention from the complex context of the place, and it operates with a form of universalism that tends to exclude the globally conditioned local and financial crises. Especially National Geographic, which is funded by Gulf Oil, and WWF, which prefers to act as an unpolitical international organization, refrain - like thousands of animal shows on TV - from addressing concrete examples of destructive global exploitation of resources, at the same time as appealing to ecological consideration of endangered species in generalized rhetorical wording. As opposed to more radical animal rights activists, for whom Dian Fossey can be seen as the inspiration, which often operate by anthropomorphizing animals and demonizing humans, the Virunga film views human and animal rights as two sides of the same coin. Whereas comments on the Internet concerning both Fossey's films and Virunga include numerous xenophobic comments in the vein of wishing that the native Batwa will 'burn up in Hell', Virunga is an attempt to confront the viewer without the use of compassionate rhetoric, through a global mass medium, with what is deep down a critique of capitalism: the root of evil is first and foremost the colonial plundering of the region and the corruption of the Congolese leaders, which keeps a country like DR Congo from establishing as a functional state. Despite its enormous extent and world historical significance, DR Congo is still not a nation but rather the half-made society described by V.S. Naipaul. Furthermore, the possibility of an "imagined community" (Smith) as a basis for national identity is impeded by the division into - and reinforcement of - tribes, which the Belgian colonial administration initiated with its anthropological and administrative segregation of the native population into ethnographic part systems and tribes that were subsequently reinforced and made absolute as strategic pieces in the political game that followed independence.

Furthermore, the post-colonial plundering of diamonds and coltan for the global market has split the Kivu district especially into very violent duchies. SOCo's activities are only the most recent step in this development, which will prolong and intensify the violent conflicts without allowing the local population to benefit from the proceeds, at 
the same time as contributing to the likely extinction of the last mountain gorillas. The Virunga film is by no means sentimental; rather, it is critical in its efforts to protect a unique place against destruction without appealing to universal human or animal rights. The film is not a standardized testimony; nevertheless, it is shocking because it conveys a concrete truth about the continued, ruthless plundering of Africa. It urges the viewer to act politically instead of being scared by the spectacular violence that is part of a calculated media strategy aiming to oppress the local population and disseminated by global media and rights campaigns - making sure that international society stays paralyzed and powerless in an enclave that appears to be, doomed and beyond the reach of rationality and solidarity. ${ }^{5}$

The Virunga film is an effort to counteract the literary and political influence of the myth of the Dark Continent and the long-term effect of the topos 'the Heart of Darkness', which currently serve the negative efforts of the oil industry, and - most recently - the sensationalistic media coverage of the Ebola outbreak in 2014 and the outbreak in 2018 in the North Kivu Province. ${ }^{6}$

\section{BIBLIOGRAPHY}

Andersen, Frits. The Dark Continent? Images of Africa in European Narratives about the Congo. Gylling: Aarhus University Press, 2016.

Battani, Marshall. “Atrocity Aesthetics: Beyond Bodies and Compassion”. Afterimage (2011).

Burton, Richard F. The Lake Regions of Central Africa, A Picture of Exploration. London: Longman, Green, Longman and Roberts, 1860.

Conniff, Richard. “Discovering Gorilla”. Evolutionary Antropology (2009).

“Du Chaillu's Adventures in Equatorial Africa”. The Edinburgh Review 01.071861.

Du Chaillu, Paul. The Country of the Dwarfs. London: Harper \& Brothers, 1901.

Fossey, Dian. Gorillas in the Mist. London: Phoenix, 1981.

Geetleman, Jeffrey. “Oil Dispute Takes a Page From Congo's Bloody Past”. New York Times 15.11.2014

Gehrmann, Susanne. Congo-Greuel. Zur literarischen Konfiguration eines kolonialkritischen Diskurses (1890-1910). Hildesheim: Georg Olms Verlag, 2003.

Ghosh-Schellhorn, Martina (ed.): Writing Women Across Borders and Categories. Miting Women Across Borde

Giles-Vernick, Tamara og Stephanie Rupp. "Visions of Apes, Reflections on Change: Telling Tales of Great Apes in Equatorial Africa". African Studies Review 49, 1 (2006).

Grant, Kevin. A Civilised Savagery. Britain and the New Slaveries in Africa, 1884-1926. London:

Routledge, 2005. 
Grant, Kevin. "Christian critics of empire: Missionaries, lantern lectures, and the Congo reform campaign in Britain”. Journal of Imperial and Commonwealth History 29, 2 (2008).

Haraway, Donna. Primate Visions: Gender, Race, and Nature in the World of Modern Science. New York: Routledge, 1989.

Hayes, Harold. The Dark Romance of Dian Fossey. New York: Simon \& Schuster 1990

Hodgson, Amanda. "Defining the Species: apes, savages and humans on scientific and literary writing of the 1860s". Journal of Victorian Culture (2001).

Jenkins, Mark. “Who murdered the Virunga Gorillas?”. National Geographic (2008).

Jephson, A.J. Monteney \& Henry M. Stanley: Emin Pasha and the rebellion at the equator: a story of the nine month's experiences in the last of the Soudan provinces. New York: Charles Scribner's Sons 1890.

Latour, Bruno. Science in action: how to follow scientists and engineers through society. Cambridge Mass.: Harvard University Press, 1987.

Lifshey, Adam. "An Américain in Africa. The Transatlantic Creations of Paul Belloni du Chaillu”. Journal of Transnational American Studies 3, 1 (2011).

Livingstone, David. Narrative of an expedition to the Zambesi and its tributaries, and of the discovery of the lakes Shriwa and Nyassa: 1838-1864. London: John Murray, 1865.

Massey, Doreen. “A Global Sense of Place”. Space, Place and Gender. Minneapolis: University of Minnesota Press, 1994

Miller, John. "Meat, Cannibalism and Humanity in Paul du Chaillu's Explorations and Adventures in Equatorial Africa". Gothic Studies 16, 1 (2014).

Morel, Edmund D. Red Rubber. The Story of the Rubber Slave Trade Flourishing on the Congo in the Year of Grace 1906. London: T. Fisher Unwin, 1906.

Mowat, Farley. Dian Fossey og bjerggorillaerne i Afrika. København: Samleren, 1988.

Peffer, John. "Snap of the Whip/Crossroads of Shame. Flogging, Photography, and the Representation of Atrocity in the Congo Reform Campaign". Visual Anthropology Review 24 (2008). Ringer, Greg. “Gorilla tourism”. Alternatives Journal 28, 4 (2002).

Salak, Kira. "Places of Darkness". National Geographic Adventure (2004).

Salopek, Paul F. “The Mountain Gorillas of Africa. A Fragile Home Threatened by War”. National Geographic 188, 4 (1995).

Schaffer, Marguerite (ed.): Rendering Nature: Animals, Bodies, Places, Politics. Philadelphia: University of Pennsylvania Press, 2015.

Sliwinski, Sharon. "The Childhood of Human Rights: The Kodak on the Congo". Journal of Visual Culture (2006).

Smith, Anthony D. “The Nation: Invented, Imagined, Reconstructed?”. Millennium: Journal of International Studies 20, 3 (1991).

Speke, John. Journal of the Discovery of the Source of the Nile. Lonson: Blackwood and Sons, 1863.

Stanley, Henry M. Through the Dark Continent or The sources of the Nile, around the great lakes of equatorial Africa, and down the Livingstone River to the Atlantic Ocean. Hamburg: Grädener 1878. 
Thompson, T. Jack. "Light on the dark continent: The photography of Alice Seely Harris and the Congo atrocities of the early twentieth century". International Bulletin of Missionary Research (2002).

Torgovnick, Marianna: Primitive Passions: Men, Women, and the Quest for Ecstacy. New York: Knopf Doubleday Publishing Group, 1997

Twain, Mark. King Leopold's Soliloquy. Boston Mass.: The P.R. Warren Company 1906.

Twomey, Christina. "Framing Atrocity: Photography and Humanitarianism". History of Photography 36, 3 (2012).

Whitlock, Gillian. "Remediating Gorilla Girl: Rape Warfare and the Limits of Humanitarian Storytelling”. Biography 33, 3 (2010).

“With Mr. Gorilla’s Compliments”. Temple Bar 01.11.1861.

\section{NOTES}

1. "SOCO and WWF agree way forward on future activity in Virunga National Park (DRC)" 11 June 2014. http://www.socointernational.com/. “British oil company's back-tracking on World Heritage Site looks like a ruse" 13 June 2014. http://www.globalwitness.org.library/british-oilcompany. "DR Congo seeks Virunga park boundary change". BBC News Africa. http:// www.bbc.com/news/world-africa.

2. Aaron Ross: "Congo defends right to explore oil in national parks", Reuters 15 February 2018. "Parcs de la Salonga et Virunga. WWF reste très préoccupé par le projet de production pétrolière", Le Courrier de Kinshasa, 16 July 2018.

3. Against the visual domination of the "Congolese atrocities", Nancy Rose Hunt suggests to be attentive to voices and sounds, building on her work in the recorded archives: Nancy Rose Hunt, “An Acoustic Register: Rape and Repetition in Congo" (in Stoler, Ann-Laura, ed, Imperial Debris. On Ruins and Ruination, Durham, N.C.: Duke University Press, 2013).

4. Brenda Cooper "Apes, Gender and the Jungle" in M. Ghosh-Schellhorn (ed.): Writing Women Across Borders and Categories, 2000. Marguerite Schaffer "Digit's Legacy: Reconsidering the HumanNature Encounter in a Global World" in M. Schaffer (ed.): Rendering Nature: Animals, Bodies, Places, Politics, 2015. "Dian Fossey among the Animals" in M. Torgovnick: Primitive Passions: Men, Women, and the Quest for Ecstasy, 1997.

5. See also Esther Marijnen, Judith Verweijen: "Selling green militarization: The discursive (re)production of militarized conversation in the Virunga National Park, Democratic Republic of the Congo", Geoforum 75 (2016) and Verweijen's blog in which she warns against the widely used "heart of darkness clichés" in the media coverage of the conflicts in the Virunga Park. https:// theconversation.com/why-fighting-fire-with-fire-in-drcs-virunga-park-isnt-helpingconservation-72295.

6. Lola Okolosie: "Ebola has infected public discourse with a new xenophobia", The Guardian 4 August 2014. Andrew O'Hehir: "Ebola, the "heart of darkness" and the epidemic of fear", Salon, 4 October 2014. Jean Batou: "Ebola: A Virus in the Heart of darkness", New Politics 6 November 2014. "Ebola situation reports: Democratic Republic of the Congo" http://www.who.int/ebola/ situation-reports/drc-2018/en/. "The Heart of Darkness Bleeds: Ebola Crisis in the Congo". www.reddit.com/r/Geosim/comments/8n1oyk/modevent_the_heart_of_darkness_bleeds_ebola/ 


\section{ABSTRACTS}

The article outlines some of the historical traces for the eco-crisis that presently threatens the first and most outstanding national park in Africa, homeland of the mountain gorilla. Texts and films about Virunga reiterate the same rhetorical figures that are frequently discussed in connection with Conrad's description of the Congo River, thus showing the long-term political effects of the "discours conradien". After a short description of the site, the article presents the Congo Reform Movement's campaign against the bloody repression in the Congo Free State around 1900, often referred to as the Red Rubber-regime. The article argues that we can detect similar and highly problematic rhetorical structures in the animal rights campaigns, which took on a global scale in the 1970s - initiated among others by Dian Fossey and her famous and infamous fight for the protection of mountain gorillas in the Virunga. Both human rights campaigns and animal rights campaigns share a responsibility, the author argues, for the ecocrisis at Virunga. Finally, he presents the documentary Virunga from 2014 as a model and as a rhetorical alternative.

L'article propose de retracer les pistes permettant d'expliquer l'histoire de la crise écologique qui menace aujourd'hui le premier et le plus exceptionnel des parcs nationaux d'Afrique, foyer ancestral des gorilles des montagnes. Les textes et les films sur le parc national des Virunga reprennent les mêmes figures rhétoriques qui sont fréquemment mises en relation avec la description par Conrad du fleuve Congo, montrant ainsi les effets politiques à long terme du « discours conradien ». Après une brève description du site, l'article présente la campagne lancée par l'association Congo Reform Movement contre la répression sanglante à l'encontre des populations dans l'État indépendant du Congo, résumant ce que l'on a appelé le « régime du caoutchouc rouge ». L'article défend ensuite l'idée qu'il est possible de détecter des structures rhétoriques similaires et hautement problématiques dans les campagnes pour les droits des animaux, qui ont pris une dimension mondiale dans les années 1970 et qui ont été initiées entre autres par Dian Fossey et sa lutte fameuse et pour le moins contestable pour la protection des gorilles des montagnes dans le parc des Virunga. L'auteur avance l'idée que les campagnes de défense des droits humains et les campagnes de défense des animaux partagent une responsabilité commune dans la crise écologique qui affecte le parc des Virunga. Enfin, il présente le documentaire Virunga (2014) comme un modèle de rhétorique alternative.

INDEX

Keywords: Congo, Virunga National Park, World Heritage, Exploitation, Political campaigns, Dian Fossey

\section{AUTHOR}

\section{FRITS ANDERSEN}

Frits Andersen est professeur d'Histoire de la littérature au département de Communication et de Culture de l'Université d'Aarhus au Danemark. Ses domaines de recherche comprennent le Congo, l'“orientalisme" ou l'histoire de l'esclavage. Il est l'auteur d'une somme monumentale parue en 2016, à partir de sa thèse de doctorat : The Dark Continent, Images of Africa in European 
Narratives about the Congo (Aarhus University Press). Il a récemment publié : Sydhavsøen - nydelsens geografi - The South Sea Island - the Geography of Pleasure (2018). 